\title{
SYNTHESIS AND SPECTRAL ANALYSIS OF SCHIFF BASE OF MIXED LIGAND COPPER (II) COMPLEXES
}

\author{
P. Thamizhini ${ }^{13, 凶}$, A. Sharmila ${ }^{2}$ and K. Lakshmi Prabha ${ }^{3}$ \\ ${ }^{1,2}$ PG Department of Chemistry, Cauvery College for Women (Autonomous), Affiliated to \\ Bharathidasan University, Tiruchirappalli-620 018, Tamil Nadu, India. \\ ${ }^{3}$ PG \& Research Department of Chemistry, Government Arts College, Affiliated to \\ Bharathidasan University, Tiruchirappalli-620 022, Tamil Nadu, India. \\ ${ }^{\square}$ Corresponding Author: thamizhiniperiyasamy@gmail.com
}

\begin{abstract}
The six new mixed ligand Schiff base of copper(II) complexes are synthesized from the Schiff base (HL) derived from pyrrole-2-carboxaldehyde and a pair of 2-(methylthio)aniline as primary ligands and 2,2'bipyridine(bipy) and 1,10-phenanthroline(phen) as secondary ligands. 1H-NMR, IR, electronic spectra, and conductivity measurements describe the ligand and copper(II) complexes. In nature, the molar conductance experiments of these complexes indicated non-electrolyte. A distorted octahedral geometry around the central metal ion is suggested by spectroscopic data from the complexes. Electrochemical experiments have been conducted using cyclic voltammetry. The intense signals may be assigned to the $\mathrm{Cu}{ }^{\mathrm{II}} / \mathrm{I}$ redox couple.
\end{abstract}

Key words: Schiff Base, 2,2'-Bipyridine, 1,10-phenanthroline, Copper (II) Complexes and Spectral Study. RASĀYAN J. Chem., Vol. 14, No.1, 2021

\section{INTRODUCTION}

In 1864, German chemist Hugo Schiff introduced a new class of organic compounds. This group of compounds, imines are often cited to as Schiff bases in his honour. The preparations of these compounds are simple and smart. ${ }^{1}$ Schiff bases are prepared by condensing carbonyl compound with primary amine. Schiff bases can potentially stabilize several metal ions in different oxidation states. ${ }^{2}$ For their interesting and essential properties, many Schiff bases and their complexes are studied, such as: their ability to bind oxygen, catalytic action in the hydrogenation of olefins, and the transfer of radicals, photochromic properties and complexing ability to some toxic metals. ${ }^{3}$

In biological, clinical, analytical and pharmacological fields, the Schiff base of 2-(methylthio)aniline and its complexes have a wide range of applications. ${ }^{4,5}$ For many biological processes, the Schiff base compounds playing a significant role. A characteristic and wide range of biological activities is the azomethine group in Schiff bases(-N=CH-). The growth of many tumours can be inhibited by Schiff bases. $^{6-8}$

In recent decades, mixed ligand complexes of heterocyclic bases have not only been studied because of their fascinating chemistry of coordination, but also because of their prominent biological practices towards bacteria, viruses and cancer cells. ${ }^{9,10}$ Copper can be a biologically important component and several enzymes have been identified that rely on copper for their function. Copper(II) can be a metal ion that is substitutionally volatile. In order to hold the copper(II) ion chelated in solution, multidentate ligands are assumed to be stronger than bidentate ligands. ${ }^{11,12}$

Several studies have been carried out against microbes that are contagious microbes on the inhibitory function of copper(II) complexes, depending significantly on metal chelation by an organic ligand. The nature of chelation greatly increases biological function, which has been well clarified by the chelation principle of Tweedy. ${ }^{13}$ In this article we report the synthesis and structures of the six novel copper(II) complexes, namely [Cu(HL) $\left.)_{2} \mathrm{Cl}_{2}\right],\left[\mathrm{Cu}(\mathrm{HL})\left(\right.\right.$ bipy) $\left.\mathrm{Cl}_{2}\right],\left[\mathrm{Cu}(\mathrm{HL})(\right.$ phen $\left.) \mathrm{Cl}_{2}\right],\left[\mathrm{Cu}(\mathrm{HL})_{2} \mathrm{Br}_{2}\right]$, $\left[\mathrm{Cu}(\mathrm{HL})(\right.$ bipy $\left.) \mathrm{Br}_{2}\right]$, and $\left[\mathrm{Cu}(\mathrm{HL})(\right.$ phen $\left.) \mathrm{Br}_{2}\right]$ were described. Those complexes are completely soluble in DMF. The ligand and complexes were characterized by several Spectroscopic methods.

\section{EXPERIMENTAL}

Reagents such as pyrrole-2-carboxaldehyde, 2-(methylthio)aniline were of Sigma Aldrich products. Aryl compounds of 2,2'-Bipyridine, 1,10-Phenanthroline was obtained from Sigma Aldrich. Anhydrous Copper(II) chloride and bromide was obtained to Alfa Aesar. The solvents were purified by the reported procedures. It is used to prepare ligand and complexes. 
In DMF, the molar conductivity $\left(10^{-3} \mathrm{M}\right)$ at room temperature was measured using Elico Ltd (India) conductivity meter. On a Bruker FT-NMR Spectrophotometer $(400 \mathrm{MHz})$ at $25^{\circ} \mathrm{C}$ in DMSO with tetra-methyl silane (TMS) as internal standard, 1H-Spectra of NMR were studied (only for ligand). With the Shimadzu FT-IR spectrophotometer model, by use of KBr pellets, IR spectra are registered. UV-visible absorption spectra were recorded at room temperature with the JASCOV-550 UV-Visible spectrophotometer. Using the $\mathrm{CH} 1600 \mathrm{C}$ electro chemical analyser, cyclic voltammetry measurements were made using three electrode systems containing platinum wire as an auxiliary electrode, glass carbon as a working electrode and $\mathrm{Ag} / \mathrm{AgCl}$ as a reference electrode.

\section{Synthesis of Ligand}

Preparation of 2-(methylsulfanyl)-N-(1H-pyrrol-2-ylmethylidene)aniline: (HL)

Hot ethanolic solution of 2-(methylthio)aniline $(10 \mathrm{mmol})$ and ethanolic solution of pyrrole-2carboxaldehyde $(10 \mathrm{mmol})$ were mixed in the presence of few drops con. $\mathrm{HCl}$ with continuous stirring. For 3 hours, the mixture has been refluxed. By filtration, the yellow solid substance was obtained. Washed in small quantities of ethanol and dried in desiccators. Yield: $80 \%$.

\section{Synthesis of Complexes}

[Dichlorobis(2-methylsulfanyl)-N-(1H-pyrrol-2ylmethylidene)anilinecopper(II)]: $\quad\left[\mathrm{Cu}\left(\mathrm{HL}_{\mathbf{2}} \mathrm{Cl}_{2}\right.\right.$ ] $\mathrm{CuCl}_{2}(10 \mathrm{mmol})$ and 2-(methylsulfanyl)-N-(1H-pyrrol-2-ylmethylidone)aniline $(20 \mathrm{mmol})$ are mixed in a 1:2 molar ratio of hot ethanolic $(10 \mathrm{~mL})$ solution and refluxed for three hours in the water bath. The mixture has been cooled to room temperature. To remove any of the unreacted starting materials, the solid precipitate of the complex was washed thoroughly several times with ethanol, and dried in desiccators. Yield: $80 \%$.

\section{[(2,2'-Bipyridine)dichloro(2-(methylsulfanyl)-N-(1H-pyrrol-2-ylmethylidene)aniline) copper(II)]: [Cu(HL)(bipy)Cl $\left.{ }_{2}\right]$}

$\mathrm{CuCl}_{2}(10 \mathrm{mmol})$ and 2-(methylsulfanyl)-N-(1H-pyrol-2-ylmethylidone)aniline $(10 \mathrm{mmol})$ are mixed in hot ethanolic solution $(10 \mathrm{~mL})$ and 2,2'-bipyridine $((10 \mathrm{mmol})$ was added immediately to a molar ratio of 1:1:1 and refluxed for three hours in the water bath. The mixture has been cooled to room temperature. To remove some of the unreacted starting materials, the solid precipitate of the complex was filtered and washed several times with ethanol, and dried in desiccators. Yield- $85 \%$.

\section{[Dichloro(2-(methylsulfanyl)-N-(1H-pyrrol-2-ylmethylidene)aniline)(1,10-phenanthroline) copper(II)]: [Cu(HL)(phen) $\left.\mathbf{C l}_{2}\right]$}

$\mathrm{CuCl}_{2}(10 \mathrm{mmol})$ and 2-(methylsulfanyl)-N-(1H-pyrol-2-ylmethylidone)aniline (10 mmol) are mixed in a hot ethanolic solution $(10 \mathrm{~mL})$ and 1,10-phenanthroline $(10 \mathrm{mmol})$ was immediately added to the 1:1:1 molar ratio and refluxed in a water bath for three hours. The mixture has been cooled to room temperature. To eliminate some of the unreacted starting materials, the solid precipitate of the complex was filtered and washed many times with ethanol and dried in desiccators. Yield- $87 \%$.

\section{[Dibromobis(2-methyl-sulfanyl)-N-(1H-pyrrol-2-ylmethylidene)anilinecopper(II)]: $\left[\mathrm{Cu}(\mathrm{HL})_{2} \mathrm{Br}_{2}\right]$}

$\mathrm{CuBr}_{2}(10 \mathrm{mmol})$ and 2-(methylsulfanyl)-N-(1H-pyrrol-2-ylmethylidene)aniline $(20 \mathrm{mmol})$ are mixed in hot ethanolic solution $(10 \mathrm{~mL})$ at a molar ratio of 1:2 and refluxed in the water bath for three hours. The mixture has been cooled to room temperature. To remove any of the unreacted starting materials, the solid precipitate of the complex was filtered and washed several times with ethanol to remove any unreacted starting materials and dried in desiccators. Yield : 80\%.

\section{[(2,2'-Bipyridine)dibromo(2-(methylsulfanyl)-N-(1H-pyrrol-2-ylmethylidene)aniline) copper(II)]: [Cu(HL)(bipy)Br $\left.\mathbf{B r}_{2}\right]$}

$\mathrm{CuBr}_{2}(10 \mathrm{mmol})$ and 2-(methylsulfanyl)-N-(1H-pyrrol-2-ylmethylidene)aniline $(10 \mathrm{mmol})$ are mixed in hot ethanolic solution $(10 \mathrm{~mL})$ and immediately added 2,2'-Bipyridine $(10 \mathrm{mmol})$ to the molar ratio 1:1:1 and refluxed in the water bath for three hours. The mixture has been cooled to room temperature. To remove any of the unreacted starting materials, the solid precipitate of the complex was filtered and washed several times with ethanol to remove any unreacted starting materials and dried in desiccators. Yield- $85 \%$. 
[Dibromo(2-(methylsulfanyl)-N-(1H-pyrrol-2-ylmethylidene)aniline)(1,10-phenanthroline) copper(II)]: [Cu(HL)(Phen)Br $\left.\mathbf{B r}_{2}\right]$

$\mathrm{CuBr}_{2}(10 \mathrm{mmol})$ and 2-(methylsulfanyl)-N-(1H-pyrol-2-ylmethylidene)aniline $(10 \mathrm{mmol})$ are mixed in hot ethanolic solution $(10 \mathrm{~mL})$ and immediately added 1,10 -phenanthroline $(10 \mathrm{mmol})$ to the molar ratio 1:1:1 and refluxed in the water bath for three hours. The mixture has been cooled to room temperature. To remove any of the unreacted starting materials, the solid precipitate of the complex was filtered and washed several times with ethanol to remove any unreacted starting materials and dried in desiccators. Yield- $87 \%$.

\section{Physical Characterization}

\section{RESULTS AND DISCUSSION}

The complexes $\left[\mathrm{Cu}(\mathrm{HL})_{2} \mathrm{Cl}_{2}\right]$ and $\left[\mathrm{Cu}(\mathrm{HL})_{2} \mathrm{Br}_{2}\right]$ are Blackish green colour, $\left[\mathrm{Cu}(\mathrm{HL})(\right.$ bipy $\left.) \mathrm{Cl}_{2}\right]$ and $\left[\mathrm{Cu}(\mathrm{HL})\left(\right.\right.$ bipy) $\left.\mathrm{Br}_{2}\right]$ are pale green colour, $\left[\mathrm{Cu}(\mathrm{HL})(\mathrm{phen}) \mathrm{Cl}_{2}\right]$ and $\left[\mathrm{Cu}(\mathrm{HL})(\mathrm{phen}) \mathrm{Br}_{2}\right]$ are green colour and air stable. ${ }^{13}$ All complexes were soluble in DMF. But in water and in common organic solvents, such as chloroform and acetonitrile, they are insoluble. ${ }^{14,15}$

\section{Electrical Conductivity}

The electrolytic nature of the copper(II) complexes has been carried out at room temperature in a $\operatorname{DMF}\left(10^{-3} \mathrm{M}\right)$ solution. ${ }^{16}$ The conductivity $\left(\lambda_{\mathrm{m}}\right)$ value ranges from $26,6,8,18,12$, and $10 \Omega^{-1} \mathrm{~cm}^{2} \mathrm{~mol}^{-1}$. The analysis showed that all complexes seem to be non-electrolyte nature. ${ }^{17}$ Inside this coordination sphere, the anions were coordinated.

Table-1: The Molar Conductivity of the Copper(II) Complex

\begin{tabular}{c|c}
\hline Complexes & Molar Conductance $\Omega^{-1} \mathrm{Cm}^{2} \mathrm{~mol}^{-1}$ \\
\hline$\left[\mathrm{Cu}(\mathrm{HL})_{2} \mathrm{Cl}_{2}\right]$ & 26 \\
\hline$\left[\mathrm{Cu}(\mathrm{HL})(\right.$ bipy $\left.) \mathrm{Cl}_{2}\right]$ & 6 \\
\hline$\left[\mathrm{Cu}(\mathrm{HL})(\right.$ phen $\left.) \mathrm{Cl}_{2}\right]$ & 8 \\
\hline$\left[\mathrm{Cu}(\mathrm{HL})_{2} \mathrm{Br}_{2}\right]$ & 18 \\
\hline$\left[\mathrm{Cu}(\mathrm{HL})(\right.$ bipy $\left.) \mathrm{Br}_{2}\right]$ & 12 \\
\hline$\left[\mathrm{Cu}(\mathrm{HL})(\right.$ phen $\left.) \mathrm{Br}_{2}\right]$ & 10 \\
\hline $\mathrm{HL}=2-($ methylsulfanyl)-N-(1H-pyrrol-2-ylmethylidene)aniline
\end{tabular}

\section{Spectral Characterization}

\section{${ }^{1}$ H NMR}

The structure of the ligand confirmed by ${ }^{1} \mathrm{H}$ NMR spectrum. ${ }^{18}$ The $1 \mathrm{H}$ ligand NMR spectrum reveals a well-resolved signal as shown in the Fig.-1. The Schiff base ligand of 1H NMR spectrum reveals a singlet due to proton of pyrrole at $11.90 \mathrm{ppm}(\mathrm{s}, 1 \mathrm{H}, \mathrm{NH})$. The azomethine proton occur at $8.60 \mathrm{ppm}$ $(\mathrm{s}, 1 \mathrm{H}, \mathrm{HC}=\mathrm{N})$ and seven aromatic protons have appeared at 7.50-8.40 $\mathrm{ppm}(\mathrm{m}, 7 \mathrm{H}, \mathrm{ArH})$. The signals at $2.60 \mathrm{ppm}\left(\mathrm{s}, 3 \mathrm{H}, \mathrm{S}-\mathrm{CH}_{3}\right)$ which were assigned to protons of methyl group. ${ }^{19,20}$

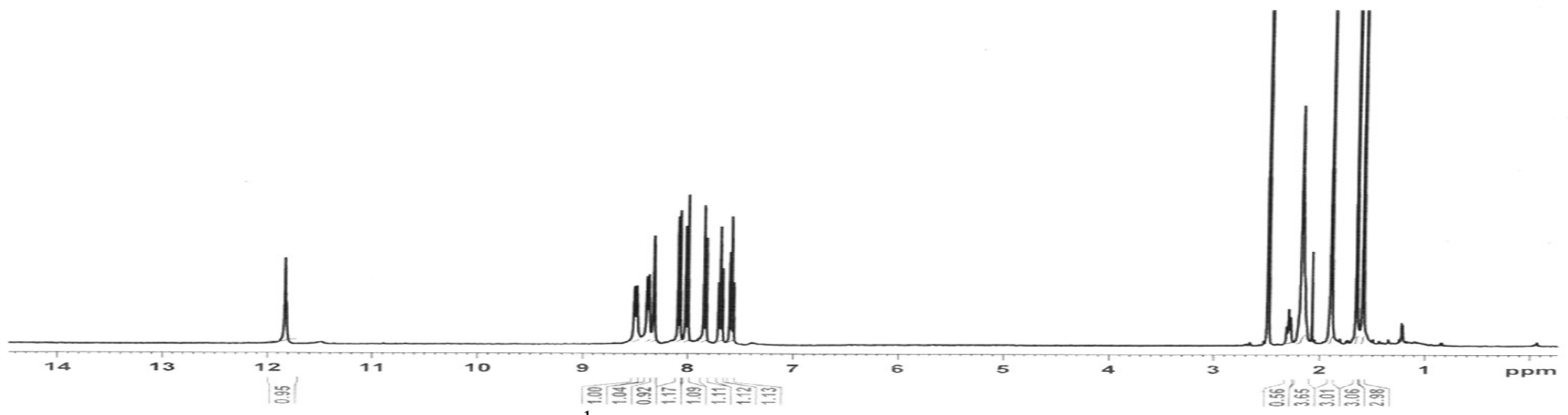

Infrared Spectra

Fig.-1: ${ }^{1} \mathrm{H}$ NMR Ligand Field Spectra

In order to determine the ligand's bonding interaction with the metal ion, the IR spectra of the prepared complexes were reported. ${ }^{21}$ The IR spectral descriptions of the copper(II) complexes are described in Table- 2 .

Table-2: Fundamental IR Frequencies of Copper(II) Complexes (in $\mathrm{Cm}^{-1}$ )

\begin{tabular}{c|c|c|c|c|c|c|c}
\hline Complexes & $\begin{array}{c}v(\mathrm{HC}=\mathrm{N}) \\
\mathrm{Cm}^{-1}\end{array}$ & $\begin{array}{c}v(\mathrm{C}-\mathrm{S}) \\
\mathrm{Cm}^{-1}\end{array}$ & $\begin{array}{c}v(\mathrm{C}=\mathrm{N}) \\
\mathrm{Cm}^{-1} \\
(\mathrm{bipy})\end{array}$ & $\begin{array}{c}v(\mathrm{C}=\mathrm{N}) \\
\mathrm{Cm}^{-1} \\
(\mathrm{phen})\end{array}$ & $\begin{array}{c}v(\mathrm{M}-\mathrm{N}) \\
\mathrm{Cm}^{-1}\end{array}$ & $\begin{array}{c}v(\mathrm{M}-\mathrm{S}) \\
\mathrm{Cm}^{-1}\end{array}$ & $\begin{array}{c}v(\mathrm{M}-\mathrm{X}) \\
(\mathrm{X}=\mathrm{Cl}, \mathrm{Br}) \\
\mathrm{Cm}^{-1}\end{array}$ \\
\hline Free ligand & 1615 & 1483 & 1443 & 1421 & - & - & - \\
\hline
\end{tabular}


RASĀYAN J. Chem.

Vol. 14 | No. 1 |288-294| January - March | 2021

\begin{tabular}{c|c|c|c|c|c|c|c}
\hline$\left[\mathrm{Cu}(\mathrm{HL})_{2} \mathrm{Cl}_{2}\right]$ & 1575 & 1460 & - & - & 416 & 675 & 374 \\
\hline$\left[\mathrm{Cu}(\mathrm{HL})(\text { bipy)Cl})_{2}\right]$ & 1602 & 1469 & 1440 & - & 420 & 655 & 372 \\
\hline$\left[\mathrm{Cu}(\mathrm{HL})\left(\right.\right.$ phen) $\left.\mathrm{Cl}_{2}\right]$ & 1602 & 1459 & - & 1401 & 450 & 620 & 370 \\
\hline$\left[\mathrm{Cu}(\mathrm{HL})_{2} \mathrm{Br}_{2}\right]$ & 1580 & 1460 & - & - & 458 & 607 & 376 \\
\hline$[\mathrm{Cu}(\mathrm{HL})($ bipy)Br \\
2 & 1602 & 1469 & 1433 & - & 445 & 632 & 373 \\
\hline$\left[\mathrm{Cu}(\mathrm{HL})(\right.$ phen $\left.) \mathrm{Br}_{2}\right]$ & 1604 & 1470 & - & 1421 & 428 & 642 & 371 \\
\hline
\end{tabular}

$\mathrm{HL}=2$-(methylsulfanyl)-N-(1H-pyrrol-2-ylmethylidene) aniline

The $1615 \mathrm{Cm}^{-1}$ band assigned to the azomethine nitrogen atom stretching frequency present in the free ligand. ${ }^{22}$ This may be shifted to the lower frequency region, suggesting the presence of azomethine nitrogen in coordination with metal ions in the spectrum of metal complexes $\left(1604-1575 \mathrm{Cm}^{-1}\right)$. At $1443 \mathrm{Cm}^{-1}$ (free bipyridine) and $1421 \mathrm{Cm}^{-1}$ (free phenanthroline), the peak comparable to the $\mathrm{vC}=\mathrm{N}$ stretching frequency was transferred to the lower frequency range $\left(1440-1433 \mathrm{Cm}^{-1}\right)$, suggesting the coordination of the heterocyclic nitrogen atom with the metal ion. ${ }^{23,24}$ The observation of new bands of low frequency regions $\left(458-416 \mathrm{Cm}^{-1}\right),\left(675-607 \mathrm{Cm}^{-1}\right)$ and $\left(376-371 \mathrm{Cm}^{-1}\right)$ attributes of $\mathrm{v}(\mathrm{M}-\mathrm{N})$, $\mathrm{v}(\mathrm{M}-\mathrm{S})$ and $\mathrm{v}(\mathrm{M}-\mathrm{X})$ stretching vibrations in the range of these complexes showed strongest evidence of bonding. ${ }^{25}$ In the spectrum of a free ligand, these peaks were not detected.

\section{Electronic Spectra}

The electronic spectral studies of all these copper(II) complexes were reported at a concentration of $10^{-3} \mathrm{M}$ in the DMF solution and the spectral results of the complexes are shown in Table-3.

Table-3: Electronic Spectra of Copper (II) Complexes

\begin{tabular}{l|c|c}
\hline \multicolumn{1}{c|}{ Complexes } & Solvent & $\begin{array}{c}\text { UV }- \text { Vis } \\
\lambda \max (\mathrm{nm})\end{array}$ \\
\hline$\left[\mathrm{Cu}(\mathrm{HL})_{2} \mathrm{Cl}_{2}\right]$ & DMF & 1.370 \\
& & 2.690 \\
\hline$\left[\mathrm{Cu}(\mathrm{HL})(\right.$ bipy $\left.) \mathrm{Cl}_{2}\right]$ & DMF & 1.380 \\
& & 2.700 \\
\hline$\left[\mathrm{Cu}(\mathrm{HL})(\right.$ phen $\left.) \mathrm{Cl}_{2}\right]$ & DMF & 1.390 \\
& & 2.720 \\
\hline$\left[\mathrm{Cu}(\mathrm{HL})_{2} \mathrm{Br}_{2}\right]$ & DMF & 1.395 \\
& & 2.695 \\
\hline$\left[\mathrm{Cu}(\mathrm{HL})\left(\right.\right.$ bipy)Br$\left.{ }_{2}\right]$ & DMF & 1.440 \\
& & 2.730 \\
\hline$\left[\mathrm{Cu}(\mathrm{HL})(\right.$ phen $\left.) \mathrm{Br}_{2}\right]$ & DMF & 1.400 \\
& & 2.710 \\
\hline$=2-($ methylsulfanyl)-N-(1H-pyrrol-2-ylmethylidene) aniline
\end{tabular}

The copper(II) complexes of electronic spectrum showed a low intensity band in the $690-730 \mathrm{~nm}$ region assigned to a ${ }^{2} \mathrm{~B}_{1} \mathrm{~g} \rightarrow{ }^{2} \mathrm{~A}_{2} \mathrm{~g}$ transition. The band's broadness is due to the distortion of JahnTeller. Such data suggest that octahedral geometry is distorted ${ }^{26}$ for these copper(II) complexes. Due to a LMCT (ligand to metal charge transfer) transition, a moderately strong band noted in the range of $370-440 \mathrm{~nm}$ is observed for these copper(II) complexes. ${ }^{27}$

\section{Electro Chemical Study}

A significant parameter is the redox potential, since it characterizes the redox centre's ability to pass electrons and to serve as a redox catalyst. The redox activity of the metal center is often determined by the existence of the attached ligands to the metal in metal complexes. ${ }^{28}$

In the potential set $-1.5 \mathrm{~V}$ to $+1.5 \mathrm{~V}$ the cyclic voltammogram of copper(II) complexes at scan rate of $100 \mathrm{mV} / \mathrm{s}$, phosphate buffer-containing DMF solutions, using glassy carbon working electrode, and their electrochemical data are presented in Table-4.

Table-4: $E_{p c}, E_{p a}$ and $\Delta E_{p}$ Values of Copper(II) Complexes

\begin{tabular}{l|c|c|c}
\hline \multicolumn{1}{c|}{ Complexes } & $\begin{array}{c}\text { Cathodic Potential Value } \\
\mathrm{E}_{\mathrm{pc}}(\mathrm{V})\end{array}$ & $\begin{array}{c}\text { Anodic Potential Value } \\
\mathrm{E}_{\mathrm{pa}}(\mathrm{V})\end{array}$ & $\begin{array}{c}\mathrm{E}_{\mathrm{p}} \text { of } \\
\mathrm{Cu}(\mathrm{II}) / \mathrm{Cu}(\mathrm{I}) \text { Couple }(\mathrm{V})\end{array}$ \\
\hline$\left[\mathrm{Cu}(\mathrm{HL})_{2} \mathrm{Cl}_{2}\right]$ & 0.599 & 0.462 & 0.137 \\
\hline$\left[\mathrm{Cu}(\mathrm{HL})(\right.$ bipy $\left.) \mathrm{Cl}_{2}\right]$ & -0.297 & -0.204 & 0.093 \\
\hline
\end{tabular}


RASĀYAN J. Chem.

Vol. 14 | No. 1 |288-294| January - March | 2021

\begin{tabular}{l|c|c|c}
\hline$\left[\mathrm{Cu}(\mathrm{HL})(\mathrm{phen}) \mathrm{Cl}_{2}\right]$ & -0.287 & -0.179 & 0.108 \\
\hline$\left[\mathrm{Cu}(\mathrm{HL})_{2} \mathrm{Br}_{2}\right]$ & -0.204 & -0.125 & 0.079 \\
\hline$\left[\mathrm{Cu}(\mathrm{HL})(\mathrm{bipy}) \mathrm{Br}_{2}\right]$ & -0.225 & -0.137 & 0.088 \\
\hline$\left[\mathrm{Cu}(\mathrm{HL})(\mathrm{phen}) \mathrm{Br}_{2}\right]$ & 0.226 & 0.162 & 0.064 \\
\hline
\end{tabular}

$\mathrm{HL}=2$-(methyl sulfanyl)-N-(1H-pyrrol-2-ylmethylidene)aniline

The copper(II) complexes display a potential anodic peak, Epa $=-0.125$ to $+0.462 \mathrm{~V}$, and a potential $\mathrm{Epc}=-0.204$ to $+0.599 \mathrm{~V}$ cathodic peak, the difference between peaks, $\Delta \mathrm{Ep}=0.064$ to $0.137 \mathrm{~V}$. The $\Delta$ Ep values for copper(II) complexes was found to be greater than Nernstian values ( $\Delta \mathrm{Ep} \approx 0.059 \mathrm{~V})$. This indicated that copper(II) complexes have demonstrated a quasi-reversible mechanism of electron transfer involving $\mathrm{Cu}(\mathrm{II}) / \mathrm{Cu}(\mathrm{I})$ couples. ${ }^{29-31}$

\section{Proposed Structure of the Complexes}

The possible structure of the copper(II) complexes is expected to give, based on the conductance measurements and the spectral data obtained, as in Figs.-2 to 7.

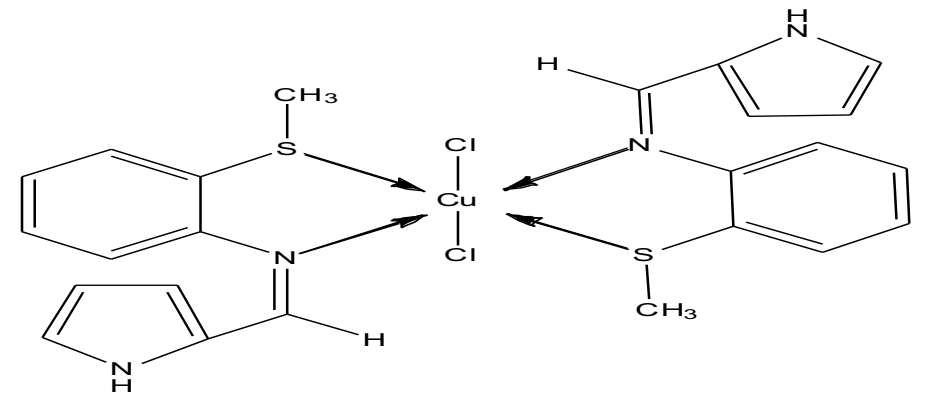

Fig.-2: [Dichlorobis(2-methyl-sulfanyl)- N-(1H-pyrrol-2ylmethlidene)aniline copper(II)]

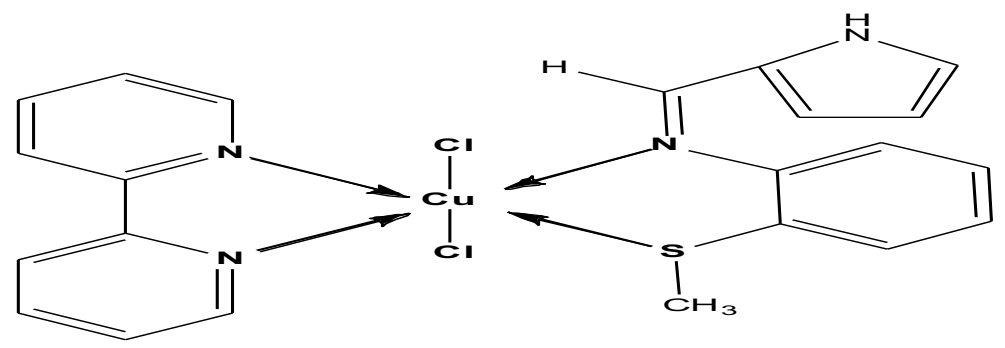

Fig.-3: [(2,2'-Bipyridine)dichloro(2-(methylsulfanyl)-N-(1H-pyrrol-2-ylmethylidene) aniline)copper(II)]

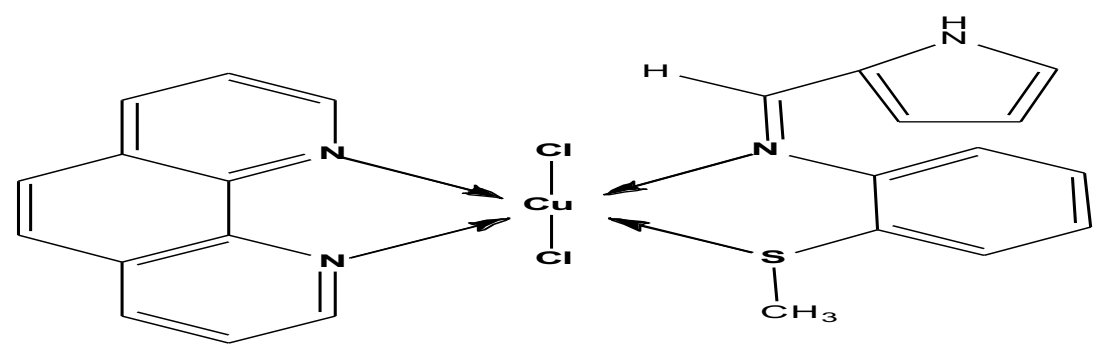

Fig.-4: [Dichloro(2-(methylsulfanyl)-N-(1H-pyrrol-2-ylmethylidene)aniline)(1,10 - phenanthroline)copper(II)]

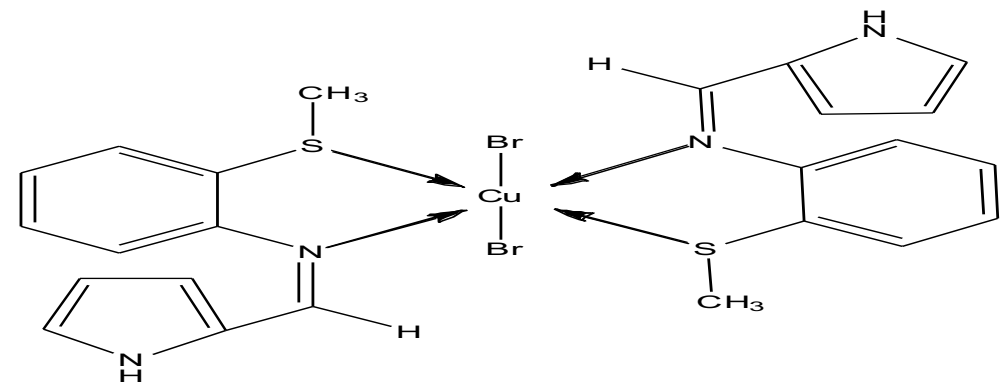

Fig.-5: [Dibromobis(2-methyl-sulfanyl)- N-(1H-pyrrol-2ylmethlidene)aniline copper(II)] 


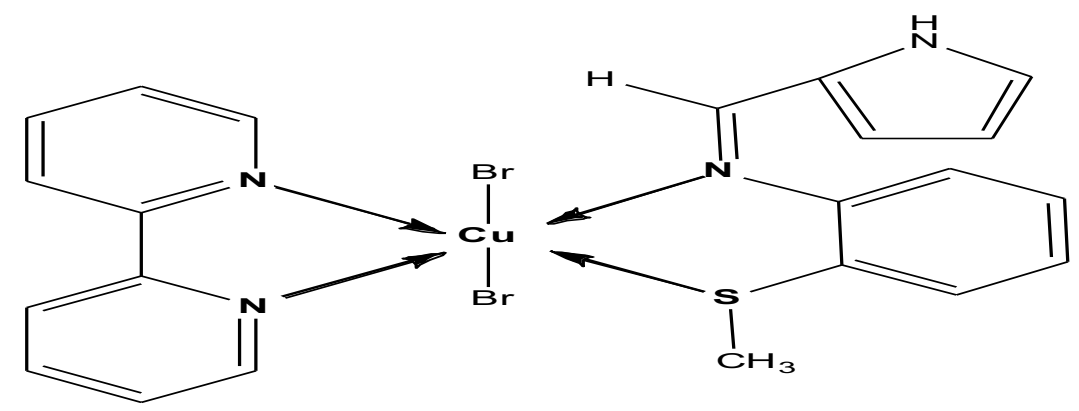

Fig.-6: [(2,2'-Bipyridine)dibromo (2-(methylsulfanyl)-N-(1H-pyrrol-2-ylmethylidene) aniline)copper(II)]

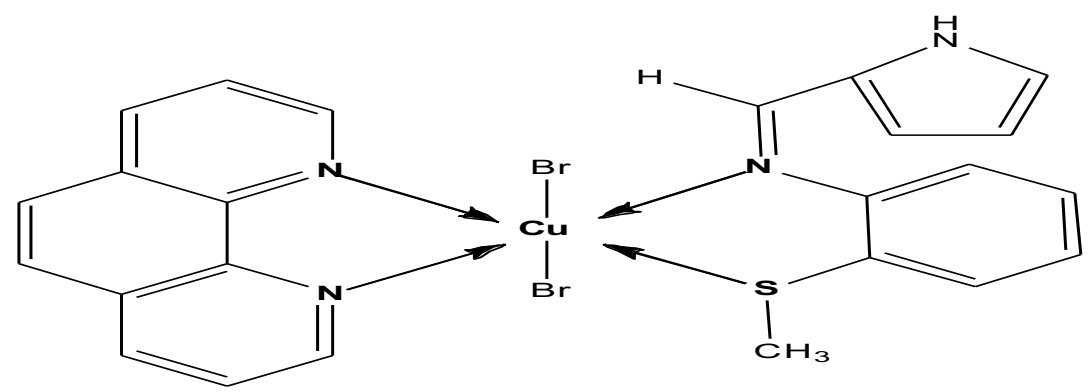

Fig.-7: [Dibromo(2-(methylsulfanyl)-N-(1H-pyrrol-2-ylmethylidene)aniline)(1,10 phenanthroline)copper(II)]

\section{CONCLUSION}

In this research, Researchers prepared the Schiff base ligand and copper(II) complexes with Schiff base ligand, 2,2- Bipyridine and 1,10-Phenanthroline. Via physiochemical and spectroscopic methods, the bonding mode and general structure of the complexes were determined. The IR spectra are coordinated with metal ions through azomethine nitrogen, thiolate sulphur, heterocyclic nitrogen atom, chloride, and bromide ions to illustrate the Schiff base and Schiff base of mixed ligand of copper(II) complexes. Accordingly, for these copper(II) complexes, the distorted octahedral geometry was suggested in associated with electronic spectra. A metal cantered electro activity within the potential range is indicated by the electrochemical data of the complexes. Work now is in progress of biological applications of DNA binding, DNA cleavage, and anti-microbial activity of these copper(II) complexes will be done in this area.

\section{ACKNOWLEDGEMENT}

We thank DST - FIST for the financial support to Cauvery College for Women, Ref. No:SR/FIST/college-246/2015(c) dated 16.06.2016 under "level -0" program for the research instruments facility.

\section{REFERENCES}

1. Chandra Irawan, Luthfiyah Nur, BellaMelli Sani and Hanafi, Rasayan Journal of Chemistry 12(2), 951(2019), DOI:10.31788/RJC.2019.1225063

2. Jagvir Singh, Anuradha, Pradeep Kumar, Mordhwaj and Ravikumar, Asian Journal of Chemistry 31(10), 2357(2019), DOI:10.14233/ajchem.2019.22049

3. G.G. Mohamed, M.M. Omar and A.M. Hindy, Turkish Journal of Chemistry 30, 361(2006).

4. N. Raman, J. Dhaveethu Raja and A. Sakthivel, Journal of Chemical Sciences 119(4), 303(2007)

5. R. Elayaperumal, M. Kiruthika and P. Dharmalingam, Journal of Pharmacy Research 7, 281(2013), DOI:10.1016/j.jopr.2013.04.029

6. Dr. A. Xavier and N. Srividhya, IOSR Journal of Applied Chemistry, 11, 06(2014)

7. M. Sunita, B. Anupama, B. Ushaiah, and C. Gyana Kumari, Arabian Journal of Chemistry 10, S3367(2017), DOI:10.1016/j.arabjc.2014.01.017

8. V.S.V. Satyanarayana, P. Sreevani, Amaravadi Sivakumar and V. Vijayakumar, ARKIVOC 221 (2008).

9. Md. Belayet Hossain, M. Saidul Islam, Md.Nazmul Hassan, M.A Yousuf and M. Abdus Salam, Daffodil International University of Science and Technology, 4(1) (2009). 
10. M. Barcelo-Oliver, A.Garcia-Raso, A.Terron, E.Molins, M.J. Prieto, V.Moreno, J.Martinez, V. Liado, I. Lopez, A .Gutierrez and P.V. Escriba, Journal of Inorganic Biochemistry, 101, 649 (2007), DOI:10.1016/j.jinorgbio.2006.12.008

11. Umendra Kumar and Sulekh Chandra Journal of Saudi Chemical Society 15, 187 (2011), DOI: $10.1016 /$ j.jscs.2010.08.002

12. G.R. Pandhare, V.M. Shindea and Y.H. Deshpandep, Rasayan Journal of Chemistry 1(2), 337 (2008).

13. M. M. Haque, Md. Kudrat-E-Zahan, Laila Arjuman Banu, Md. Shariful Islam and M. S. Islam, Bioinorganic Chemistry and Applications, 7, (2015), DOI:10.1155/2015/923087

14. R. Neelaveni, S. Vasantha, R. Keerthana S Sivakolunthu and T. Angeline, Asian Journal of Pharmaceutical and Clinical Research, 9(3), 277(2016).

15. M. Salihović, M. Pazalja, I. Mahmutović-Dizdarević, A.Jerković-Mujkić, J.Suljagić, S. ŠpirtovićHalilović and A. Šapčanin, Rasayan Journal of Chemistry, 11(3), 1074(2018), DOI: 10.31788/RJC.2018.1133077

16. Md. Kudrat-E-Zahan, Md. Masuqul Haque, Lokonuzzaman Ahmmed, M. Sher Ali and Md. Saidul Islam, International Journal of Materials Science and Applications, 4(2), 120(2015), DOI: $10.11648 / j . j \mathrm{jmsa} .20150402 .18$

17. M. Sivasankaran Nair, D. Arish and J. Johnson, Journal of Saudi Chemical Society, 20, S591 (2016), DOI:10.1016/j.jscs.2013.04.007

18. Padma Sikarwar, Sapna Tomar and A.P. Singh, American Journal of Chemistry, 6(5), 119(2016), DOI:10.5923/j.chemistry.20160605.02

19. Vivekanand D.Biradar and B.H.M. Mruthyunjayaswamy, The Scientific World Journal, 451629, 13(2013), DOI:10.1155/2013/451629

20. M.J. Jisha and C. Isac Sobana raj, International Journal of Scientific and Research Publications, 7(10), 2250(2017).

21. Thahira B.S.A. Ravoof, Karen A. Crouse, M. Ibrahim M. Tahir, Andrew R. Cowley and M. Akbar Ali, Polyhedron 26, 1159(2007), DOI:10.1016/j.poly.2006.03.007

22. Dobojyoti Lahiri, Ritankar Majumdar, Dibyandu Mallick, Tridib K. Goswami, Rajan R. Dighe and Akil R.Chakaravarty, Journal of Inorganic Biohemistry, 105, 1086(2011), DOI:10.1016/j.jinorgbio.2011.05.010

23. AP. Arumugam, G. Elango and S. Guhanathan, Journal of Chemistry Environmental Science and its Applications, 3(1), 75(2017)

24. Sahar Alimirzaei, Mahdi Behzad, Shamsozoha Abolmaali and Zeinab Abbasi, Journal of Molecular Structure, 1200, 127(2020), DOI:10.1016/j.molstruc.2019.127148

25. Aysegul Golcu, Mehmet Tumer, Havva Demirelli and R. Alan Wheatley, Inorganica Chimica Acta, 358, 1785(2005), DOI:10.1016/j.ica.2004.11.026

26. N. Raman and Johnson Raja, Journal of Serbian Chemical Society 72(10), 983(2007), DOI: 10.2298/JSC0710983R

27. Luigi Casella and Michele Gullotti, Inorganic Chemistry (22), 2259(1983), DOI:10.1021/ic00158a008

28. D. Sakthilatha, A.Deepa and R.Rajavel, Synthesis and Reactivity in Inorganic, Metal-Organic and Nano- Metal Chemistry, 45, 286(2015), DOI:10.1080/15533174.2013.831880

29. G. Sivasankari, S.Boobalan, P. Mekala and S. Gowri, Rasayan Journal of Chemistry 12(4), 1985 (2019), DOI:10.31788/RJC.2019.1245430

30. Kuheli Das, Sanchita Goswami, Belete B. Beyene, Amogne W. Yibeltal, Eugenio Garribba, Antonio Frontera and Amitabha Datta, Polyhedron, 159, 323(2018), DOI:10.1016/j.poly.2018.11.058

31. M. Vijayalakshmi, Rasayan Journal of Chemistry 11(2), 857(2018), DOI:10.31788/RJC.2018.1123033

[RJC-5890/2020] 